\title{
Foreign Policy's Role in Promoting Development: the Brazilian and Turkish Cases
}

\section{Alexandre Piffero Spohr* \\ André Luiz Reis da Silva**}

\begin{abstract}
Foreign policy's role in promoting a country's development is a matter of great importance for understanding its national trajectory, especially in the case of an emerging country. This article aims to analyse lines of action of foreign policy that help emerging countries' development. In order to do so, it has as its main hypothesis that six lines of action work together towards that goal: (a) trade promotion; (b) investment policy; (c) economic, financial, and commercial negotiations; (d) resource exploration rights; (e) international co-operation; and (f) international projection. To verify their applicability, it analyses the cases of two emerging countries, Brazil and Turkey.
\end{abstract}

Keywords: Foreign Policy; Development; Brazil; Turkey; Semi-Periphery.

\section{Introduction}

Current international dynamics have been greatly influenced by the emergence of middle powers, or emerging powers, whose main goal both domestically and internationally has been to promote their development and to increase their projection. However, little has been written on how these countries' foreign policy can help their development goals, as most works on this relation, for instance Hyman (2010) and Maxwell (2007), focus on the instruments that centre countries have created to help promote the periphery's development. Nonetheless, this pattern of analysis undermines dependent countries' capabilities of self-help, maintaining asymmetries.

This article aims to fill the gap in foreign policy analysis when it comes to its relation with the development policies pursued at home. One is used to hearing that a country's foreign policy aims to promote its development, but rarely does one hear about the mechanisms through which foreign policy can actually pursue that goal. This subject is closely related to the lack of public debate on foreign policy and international relations (IR), as most people cannot really grasp how the actions their states undertake internationally af-

\footnotetext{
* Federal University of Rio Grande do Sul, Porto Alegre-RS, Brazil; alexandre.spohr@gmail.com.

** Federal University of Rio Grande do Sul, Porto Alegre-RS, Brazil; reisdasilva@hotmail.com.
} 
fect their common lives. In this sense, this article aims to shed light on the benefits foreign policy can bring to a country's population.

The research whose results this article is set to present had as its main question: How does foreign policy help to promote semi-periphery countries' development goals? It based its actions on the following hypothesis: Foreign policy has a set of aspects through which it can help ensure the necessary environment to help the country develop. In order to overcome the lack of attention to development aspects of foreign policy studies, elements from both foreign policy analysis and international political economy (IPE) shall be combined, as supported by Caporaso et al (1986). In this sense, a thorough revision of different disciplines' literature was conducted in order to create a model of analysis, which was later evaluated through semi-structured interviews with members of the diplomatic body and scholars from both analysed countries. The interviews focused on the countries' foreign ministries and specialised agencies with similar activities regarding foreign interaction.

Comparing the two cases was fruitful for understanding the similarities presented by countries on the intermediary level of power in the international system. In addition, it helped give the model more depth and granted the analysed lines of action more complexity. The case selection was based on three elements. First, both are classified as part of the semi-periphery by Wallerstein (1976). Second, AKP's rise in Turkey (2002) and PT's election in Brazil (2003) caused similar changes to their foreign policies. Finally, the combination of systemic similarities, although attenuated by Brazil's larger relative size, with important differences in terms of regional situation and economic model grants more applicability to the model and allows for greater reflection on how these different elements affect development.

This research is based on a previous discussion on the definition of development as presented by Amsden (2001), Furtado (2000), Jaguaribe (2013a), and Wallerstein (1988), among others. Through this discussion, development can be understood as the process of increasing utilisation of available resources in order to ensure a more favourable interaction in world markets and, so, generate better conditions for the people through better wages and reduced socio-economic inequality. This definition meets resistance from some policymakers who understand development as solely economic growth.

Case analysis was conducted synthetically, focusing on framing the countries' foreign policy actions into the lines presented in the model. So, albeit recognising the complexity of the foreign policy decision-making process, the myriad of actors that influence/define strategies and objectives in this process is not extensively tackled; nor is the weight of their roles.

Aiming to present a comprehensive understanding of foreign policy's role in promoting semi-periphery countries' development, this article is divided into five sections besides this introduction. In the next section, the model of analysis will be presented, dividing foreign policy actions into two dimensions (economic and political), which are later subdivided into lines of actions. The next two sections will apply the mentioned model to the two analysed cases, Brazil and Turkey, which were chosen due to their similarities regarding their position in the international system and due to their differences concern- 
ing their regional conditions and their political scenario. After applying the model to the countries, a comparison of the cases will be conducted in order to check its validity and to present the analytical gains achieved through the praxis. Finally, final remarks on the subject will be presented concerning the future developments of the research.

\section{Foreign policy as a tool for development}

The state's role in development promotion strategies is the theme of many political economy works. There is a strong line of thinking that understands that semi-periphery - or developing/emerging - countries present a deep need for a strong state when it comes to overcoming the gap that separates them from the centre - or developed countries. That need was registered in Western European countries after the British Industrial Revolution. For instance, Germany under Bismarck and France under Napoleon III underwent strong statist modernisation processes in the late 19th century, which Jaguaribe (2013a) described as programmed development.

Gerschenkron (1961) stated that the more backward a country is, the greater the role the state needs to play in promoting its development. Similarly, Amsden's (2001) and Chang's (2002) historical accounts on IPE present us with an overview on how the centre has traditionally tried to institutionalise its leading position by prescribing liberal policies abroad while deploying interventionist practices. In the IR area, Wallerstein (1988) and Arrighi (1990) confirm the need for a strong state presence in overcoming the gap between centre and periphery (and semi-periphery), while presenting a pessimistic view on the real opportunities for joint development of the 'backward' countries.

When analysing foreign policy's role in promoting development, one has to acknowledge the state's relevance in this process. Bearing this in mind, one can divide foreign policy into two large areas through which it influences the country's development, namely economy and politics. These can be further divided into lines of action specifically related to enhancing a country's economic growth and reducing its inequality levels, which is usually not a priority to most policymakers. In this sense, this article presents a model that helps analyse how the foreign policy-development relation operates in different cases (Figure 1).

When dealing with the economic area of foreign policy, one can distinguish three lines of action that can directly influence the country's development strategy. These lines are the following: (a) trade promotion; (b) investment policy; and (c) economic, financial and commercial negotiations. In the political area, the lines of action are more indirectly related to development promotion, as their practical effects do not reach the economic and social areas so fast, but help create a positive environment for the other lines of action to succeed. In this sense, three other lines of action can be listed: (d) resource exploration rights; (e) international co-operation; and (f) international projection. 


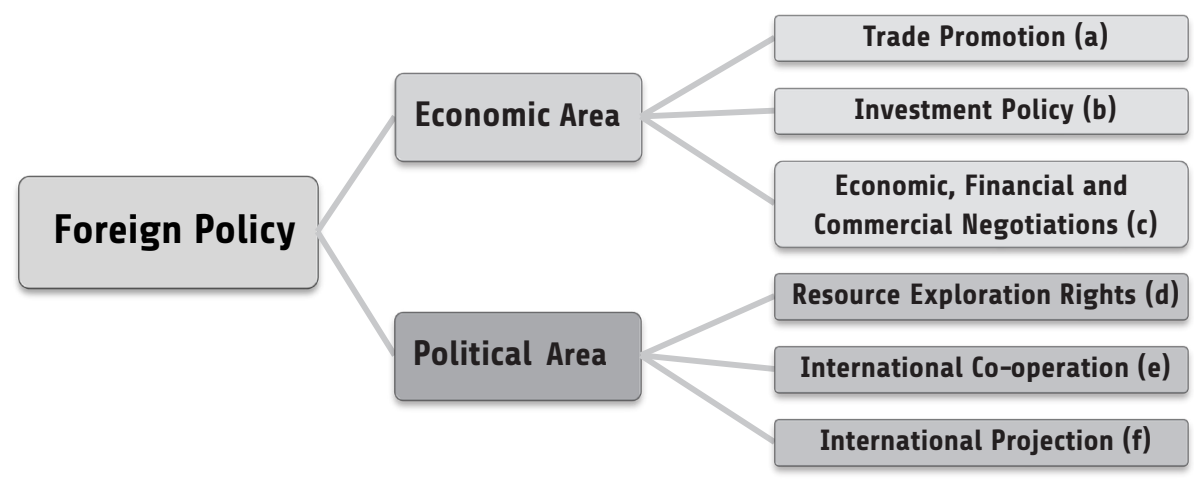

Source: Authors' elaboration.

The economic area of foreign policy has a more direct relation to the development project, especially to its economic growth perspective. This area is usually the subject of analyses that relate countries' foreign policy to their development, albeit not usually treating all lines separately and thoroughly.

The economic area's first line of action (a) is recurrently used to show the results of foreign policy to the broader public, frequently included as a proxy for success of foreign policy and/or proximity between two countries in scholarly analyses (Baumann and Moreira 1987; Souza 2002). Increasing a country's trade is a matter whose importance to foreign policymakers grew significantly in the $20^{\text {th }}$ century. According to Feder (1982), exports lead to greater economic growth than just their contribution to GDP. The greater participation of state and government leaders in implementing their country's foreign policy and their special attention to trade has caused many analysts to compare them to salesmen, a mistaken comparison according to Sérgio Danese (1999). Although criticised, this comparison allows us to deduce the great importance assigned by rulers and their foreign services to enhancing trade with the world.

Trade promotion consists not only of raising quantitatively national exports, but also of upgrading them qualitatively. Bearing in mind the aforementioned concept of development, this line of action includes actions to encourage exports with more high-value-added components. In order to do so, foreign policymakers usually try to reach new markets - formerly little interested in national goods - and to promote high-value-added goods in its trade with traditional partners. This line of action depends heavily on a domestic policy of enhancement of domestic goods' competitiveness, which is helped by improvements to workers' skill levels.

A country's investment policy (b) encompasses two positions a state can find itself in: FDI attraction, usually presented as of utmost importance in the initial stages of production diversification, and expanding national investments abroad. Fonseca (2015) under- 
stands FDI as potentially beneficial for both investor and recipient. However, the weaker side, the recipient, needs to worry about guaranteeing that capital transfers are followed by technology transfer, which is vital for development. On the investing side, expanding a country's outreach to other regions opens new opportunities for national business people to invest abroad.

The third line of action (c) tries to set up systemic conditions for a national development strategy, being a historically recent element. Its start can be pointed back to NorthSouth tensions during the Cold War. When Southern countries started to reflect upon the great gap that divided them from the North, a need for global debate on the real opportunities for development allowed by international constraints emerged. Chang's (2002) analysis of different countries' development trajectories contributes to ascertaining the need for the periphery and semi-periphery to demand conditions different from the ones already in place. As the author puts it, the centre-espoused liberalism is part of a status quo strategy, supporting conditions far from the ones they enjoyed while growing and developing socio-economically.

In this line of action, the strategy is to demand suitable conditions for development, for the elimination of developed countries' disloyal trade practices (such as subsidies, tariff and non-tariff barriers (NTBs), and dumping), for fairer intellectual property regimes (flexible to national technology generation programs), and for the possibility of developing unorthodox programmes. In this sense, Amsden (2001) presents Asian economic growth strategies that were responsible for producing high-value-added goods, gaining international competitiveness, and avoiding Northern pressures for liberalisation. Infantindustry protection and fairer international economic and trade regimes are strongly supported.

The other three lines of action have a more indirect effect on the economic growth of a country, but can contribute hugely to both aspects of development. The situation of a country's image in the international system is of utmost importance to maintaining and enhancing its trade flows, to keeping its autonomy in relation to more powerful actors, to gathering support for its positions in multilateral forums, to gaining access to more up-todate technologies, and to creating the necessary environment for its companies to increase their activities both nationally and abroad. Therefore, the political area has a positive effect on the overall outcome of the economic area and its lines of action.

What is understood by resource exploration discussions (d) is the need for a country to assure its right to explore its own natural resources. This comprehends both ownership and environmental negotiations. When joining international regimes of land and sea resource ownership and exploration, a country's foreign service tackles the issue of guaranteeing that the necessary resources for its development remain available to itself. Therefore, discussions on borders' delimitation and on law of the sea assume a strategic sense and can help ascertain the necessary means to promote economic and social development.

Similarly, environmental negotiations appear as an important arena for developing countries. The historical divide between developed and developing countries in environmental forums is the result of the confrontation of conservationist and developmentalist views on the issue. On the one hand, conservationists tend to support the zero-growth 
position, obstructing the industrialisation of periphery countries. On the other hand, developing countries raise the shared, but differentiated responsibilities flag, aiming to guarantee their right to conduct industrial projects and, thus, to develop. In this sense, the strategy is to support the right to explore the country's natural resources.

International co-operation (e) appears as a dual policy, which benefits both sides involved in the action. According to Leite (2012), co-operation presents an aspect of trade through which involved parties receive something in return for their contribution. So, a country can, as a target of foreign co-operation projects (from both countries and international organisations), receive technology, develop shared projects of resource exploration, or create programmes of inequality reduction. The pattern through which a country receives this kind of co-operation plays an important role in guaranteeing that its benefits will last and in generating conditions to eliminate the continuous need for foreign assistance.

When assuming a stronger position regarding the international order, a country can start promoting co-operation or sharing initiatives with others on a more equal basis (Amora and Corrêa, interview, 2015). As the main contributor to co-operation programs, the state enhances its international image and improves its strategy's chances of success. Therefore, proposing co-operation assumes a pivotal role in ascertaining the acceptance of economic area actions. The outreach to regions of the globe beyond traditional relations can be seen as a recurring strategy by semi-periphery countries, which, basing it heavily on co-operation and political co-ordination forums, have presented great gains regarding the increase in trade and the expansion of national investments.

International projection (f) consists in the indirect effect other aspects of foreign policy have on the aforementioned lines, and autonomy plays a major role in it. It encompasses a series of matters on the international agenda that can assume a developmentalist approach depending on the country's strategy. Overall, development and autonomy present a mutually reinforcing relation, as an increase in one can be capitalised on to enhance the other.

Autonomy is a goal shared by all states, but it appears less often in central reflections, as their autonomy is sufficiently well established. Latin American scholars, however, dedicate special attention to the subject. Vigevani and Ramazini (2014: 520, our translation) define it as the 'notion that refers to a foreign policy free of constraints imposed by powerful countries'. So, the search for autonomy aims to allow states to follow their own development strategies, without centre intervention, as it is less interested in their success.

The semi-periphery's strategy of forming demanding coalitions of similar actors from both the periphery and semi-periphery - seems a way to increase their projection and to guarantee their autonomy. However, Wallerstein (1976) pinpoints the fragility of these coalitions, as the joint rise of these countries is not possible in the current terms of the world system. He foresees the separation of ascending semi-periphery countries from the rest or the co-optation of periphery actors by central powers undermining the coalitions' strength. Thus, the foreign policymakers of those ascending countries need to address these issues in order to consolidate their claims, increasing their relative power and their political-economic space internationally. 
The last line of action serves as background to all others, as this broad strategy of enhancing its international projection ends up influencing the chances other lines of action have to succeed. When dealing specifically with semi-periphery actors, there is the need to acknowledge some obstacles to their joint rise. Wallerstein (1988) and Arrighi (1990) point out that such a rise would require simultaneous changes to economic, financial, and commercial regimes.

Decisions in all six lines of action should be made simultaneously or harmoniously, being constrained by both domestic and international variables. In this sense, FPA and IPE need to come together to allow for a greater understanding of the dynamic and of its possibilities of success, as supported by Caporaso et al (1986). As Hudson and Vore (1995) put it, there is a need for decision making to be duly analysed, which can be done through Putnam's (1988) two-level game.

Jaguaribe (2013b) states that development promotion, through domestic and international means, requires a great deal of domestic support for a certain development project. First of all, this development project is a decisive element in establishing the strategies pursued by a country in every line of action presented above. Secondly, to guarantee popular support for a specific project, a leader or ruler resorts to different strategies. Finally, when dealing with the international system, the co-ordination with other states involves the domestic support of all involved states, which makes the process even harder.

Having established the lines of action through which foreign policy helps a semiperiphery country's development strategy here, the following two sections will apply them to two cases: Brazil and Turkey. These are illustrative of the semi-periphery condition in terms of its systemic constraints and possibilities, at the same time as presenting important differences regarding their regional situation and their development model.

\section{The Brazilian case}

After the Revolution of 1930, development assumed a major role in Brazilian foreign policy, influencing its principles and values. Since then, politicians and diplomats have used many instruments, incentives, inputs, and opportunities obtained abroad to further national development. Besides its history intrinsically related to development search, Brazil is recurrently recognised as an emerging power in specialised literature, especially after its framing as part of the BRIC in 2001 and later participation in the BRICS summits.

A developmentalist line of thought ${ }^{1}$ dominated, not unchallenged, Brazilian political economy until the 1990s, having major repercussion on foreign policy. Cervo $(2008)^{2}$ states that the developmentalist paradigm ${ }^{3}$ of foreign policy prevailed until the neoliberal challenge in late 1980s. In spite of some important changes to the Brazilian political system, such as the end of Vargas Era in 1937 and the rise of the military regime in 1964, foreign policy has kept development as an important goal, although pursuing it through various strategies. Despite the decline in developmentalist thought in the 1990s, development has kept on being a major goal for foreign policymakers. The 'normal', or neoliberal, paradigm, ${ }^{4}$ despite discontinuing many practices from the previous paradigm, kept on be- 
lieving its actions were set ultimately to promote economic growth, the main component of development for most policymakers in the last century.

In the $21^{\text {st }}$ century, state action was once again believed to present the necessary means to promote development, and, so, foreign policy resumed its more active role in this process, enhancing dynamics which had previously lost importance or attention. In this context, the rise to power of the Workers' Party (PT) in 2003, after Lula's election to the presidency, was chosen as the timeframe for this analysis, in spite of changes during the period. From 2003 on, foreign policy suffered important changes, which can be duly perceived through this article's model of analysis.

Regarding the economic areas first line of action (a), there is a historical trend in Brazilian foreign policy of promoting the increase of trade with distant regions. In 1965, the Ministry of Foreign Affairs (MRE) created its Department of Trade Promotion and Investment (DPR) in order to diversify the country's exports and to solve its foreign currency needs. The DPR, together with the Ministry of Development, Industry and Foreign Trade (MDIC) and the Brazilian Trade and Investment Promotion Agency (ApexBrasil), ${ }^{5}$ is responsible for enhancing Brazilian exports and consumer markets (Souza, interview, 2015).

As the creation of the DPR suggests, trade promotion received special attention from foreign policymakers during the military regime (1964-1985). This newly created body played a special role in Embraer's first international sale ${ }^{6}$ and in Vale's first export to China. ${ }^{7}$ These actions were set in the middle of a pragmatisation process in Brazilian foreign policy, as Socialist, African, and Middle Eastern countries became new markets for Brazilian exports. In this context, Brazil's participation in the Cold War's Western bloc was attenuated, as the promotion of national industrialisation, through finding new markets and input sources, assumed a larger role (Silva and Svartman 2014). The 1990s paradigm prioritised trade liberalisation over promotion and avoided trade with so-called rogue states.

After 2003, trade promotion resumed its central role in Brazilian foreign policy. The expansion of embassies throughout the world, in the midst of an 'active and bold foreign policy' as defined by its Foreign Minister, Celso Amorim (2011), fostered broader trade flows with distant regions and enhanced commerce with traditional partners. This trend was kept as one of the priorities of Dilma's foreign policy, especially in the beginning of her second term, resulting in it being called 'results diplomacy'. Presidential trips were usually accompanied by delegations of business representatives aiming to benefit from the presidential prestige to create a better environment for business. The organisation of such trips and other initiatives was conducted in co-operation with different Ministries, such as the MDIC, the Ministry of Agriculture, Livestock and Food Supply (MAPA), and the Ministry of Tourism (Souza, interview, 2015).

The regional sphere was also an object of great concern commercially, as the integration processes - Southern Common Market (Mercosul), Union of South American Nations (Unasul), and Community of Latin American and Caribbean States (CELAC) - aimed to foster trade inside the region and to establish common dialogue mechanisms with other regions and actors. Under Mercosul's Decision 32/2000, changes to trade tariffs applied to non-members need to be discussed by all parties. Thus, Brazil has had to reach 
common goals with its neighbours to sign preference trade agreements (Costa Filho, interview, 2015). New initiatives that gathered distant regions, such as South America-Africa (ASA) and South America-Arab Countries Summits (ASPA), were followed by meetings with business representatives.

Brazil has undergone a major change in its relations with FDI during the $20^{\text {th }}$ century (b). While historically investment was almost exclusively foreign, national development has created new opportunities for Brazilian businesses. The business landscape in Brazil underwent a gradual process of transformation in the last century, after which some big national enterprises dawned among major transnational companies (Fonseca 2015). The intense support provided by the government to domestic firms played a major role in increasing their competitiveness and in allowing them to enter international markets. In this sense, in the $21^{\text {st }}$ century, the Brazilian economy has important inward and outward FDI flows, which need to be tackled in order to understand Brazilian investment policy.

FDI played a major role in the Brazilian industrialisation via the import-substitution process, as many key companies were either subsidiaries of foreign firms or received major foreign investment. In this sense, the DPR, together with the MDIC and ApexBrasil, develops a proactive strategy of promoting Brazilian investment opportunities, trying to attract more and more foreign capital (Souza, interview, 2015). Similarly, negotiations with foreign markets ally trade and investment topics, aiming to increase exports and to make investing in Brazil more appealing (Costa Filho, interview, 2015). However, the great amount of foreign companies in the country has caused a major currency exit in the factor income balance.

Alongside this capital attraction strategy, a new trend concerning FDI has emerged in Brazil as its companies became internationally competitive. In the $21^{\text {st }}$ century, the Brazilian government dedicated special attention to encouraging national companies to invest abroad, in order to increase demand and to enhance currency entries in the factor income balance, as described by Santos (2013) and Fonseca (2015). The strategy unofficially called 'national leaders' strategy, promoted, as of 2003, a new dynamic in the capital account of balance of payments, creating new opportunities for wealth and jobs generation. The National Bank for Economic and Social Development (BNDES) played a major role in this strategy, lending money for projects conducted by Brazilian firms abroad. In this sense, the BNDES has worked similarly to Eximbanks elsewhere - in China and in the USA, for instance - as theoretically presented by Amsden (2001).

National companies have benefited greatly from the expansion of Brazilian foreign policy to other regions, as business opportunities in Latin America, Africa, the Middle East, and Asia have abounded since 2003, encouraged by initiatives such as ASA, ASPA, Unasul, and CELAC (Santos 2013). The MRE has been working intensely on creating the necessary legal framework and positive environment for Brazilian investments abroad to meet their goals. According to representatives from MRE's Department of Financial Affairs and Services (DFIN), Brazil has been negotiating Investment Co-operation and Facilitation Agreements (ACFIs) with different countries ${ }^{8}$ in order to attend to national companies' needs overseas (Moretti, interview, 2015). 
During Amorim's mandate as Foreign Minister (2003-2010), Brazil assumed a major role in multilateral negotiations on various topics (c). In the World Trade Organisation (WTO), Brazil surpassed its small participation in world trade (around 1\%) and attained international recognition. Brazil assigned special attention to multilateral trade negotiations because of its potential for eliminating disloyal trade practices all over the globe, as central countries appeared reluctant to open their agricultural markets. During WTO's Doha Round, Brazil had its importance recognised after it championed the creation of a developing countries coalition, the G-20, through its inclusion in the G-4. ${ }^{9}$ WTO's Dispute Settlement System was also an important tool in Brazil's quest for fairer trade practices. Based mostly on technical and legal elements, the system has proved itself to be a vital instrument to punish the centre's disloyal trade practices, as Brazil's victory in the disputes with the USA (over cotton) and the EU (over sugar) exemplify (Amorim 2015). Roberto Azevêdo's election as WTO General-Director can be perceived as a result of Brazilian active participation in the organisation's discussions.

Both PT presidents have assigned special attention to the financial and economic multilateral agendas. While Lula's presidency aimed to reform Bretton Woods' financial institutions' quotas system, Dilma's government actively joined the other BRICS countries in creating new institutions (Lima 2015). Meanwhile, the two presidents have presented many critiques of the oligarchic means of decision-making in global financial governance. Thus, the replacement of the G-8 by the financial G-20 in 2009 as the main decision-making forum on global financial and economic regulation was celebrated in Brazil (Visentini and Silva 2010). Brazil tries to gather other emerging countries in the forum to foster development-friendly rules and projects. According to representatives from DFIN, Brazil wants to keep the G-20 away from G-8 traditional authoritarian practices (Moretti, interview, 2015).

Brazilian diplomatic history combined with its favourable regional situation played a major role in turning almost every aspect of its international projection more or less in the direction of development. Having solved its territorial disputes in the beginning of the $20^{\text {th }}$ century in a relatively peaceful manner, Brazil was able to focus its foreign policy on matters related to guaranteeing its development and autonomy. In this sense, the political area of the analysis model allows for interesting considerations in the Brazilian case.

Brazilian international activism has repercussions on both resource exploration discussion points (d). First, the struggle to guarantee its ownership over some resourceful areas can be traced back to its border definition process, which started in the middle of the $19^{\text {th }}$ century. The UN Conference on the Law of the Sea (UNCLOS) in the 1970s followed the Brazilian claim for 200 nautical miles territorial sea, as preceded and followed by other South American countries. During UNCLOS, Brazil joined other territorialist countries aiming to ensure their right to their own resources (Silva and Svartman 2014). After ratifying the 1982 final document in 1998, Brazil focused its actions in this arena on expanding its continental shelf through the mechanisms foreseen in the Convention (Marroni 2013).

Secondly, Brazil has been a vocal actor in environmental discussions, supporting the principles of 'shared, but differentiated responsibilities' and 'sustainable development' (Sil- 
va 2014). Its participation in the 1992 Earth Summit was vital to ensure that development is tackled when discussing measures to reduce climate change. In 2012, the subject of poverty was included in the discussions, because of Brazilian insistence, during Rio+20. This shows the attention Brazil always dedicates to development - also in its social aspect - on various agendas. Gathering support from similar actors is an important part of this line of action, as shown by the BASIC grouping, created in 2009.

International co-operation (e) has been an important aspect of Brazilian development promotion strategy. The creation of the Brazilian Co-operation Agency (ABC) in 1987 was an important step towards the institutionalisation of international technical cooperation in Brazil. The $\mathrm{ABC}$ aimed to rationalise efforts from different bodies and initiatives under the co-ordination of an MRE department (ABC 2015). Brazilian relations with international co-operation have undergone important changes since then. While in the $20^{\text {th }}$ century Brazil was the destination of many central countries' projects, in the $21^{\text {st }}$, Brazil has become an important source of co-operation. Foreign assistance for key projects in agriculture, industry, and infrastructure and technology creation played a major role in Brazilian development. However, as the country's economy grew, foreign aid providers (both state and international organisations) decreased, as many decided to focus their aid on specific areas. Nowadays, only Germany and Japan appear as regular co-operation providers to Brazil, as stated by ABC's representatives (Amora and Corrêa, interview, 2015).

Meanwhile, Brazil has intensively developed its aid-providing capacities, as the ABC has changed its main focus of action. In this sense, the expansion of Brazilian foreign policy in Latin America and to Africa, the Middle East, and Asia is accompanied by ABC's work as a technical co-operation provider. Many are the examples of joint programmes developed by $\mathrm{ABC}$ and other Brazilian ministries with foreign governments. The absence of conditionalities for a country to receive the aid is an important element of the co-operation provided by Brazil, as an example of South-South co-operation. However, Brazil is also benefited by its actions, as the co-operation provided reinforces the country's good international image and creates a positive environment for Brazilian businesses (Amora and Corrêa, interview, 2015). Thus, they are strongly interested in the projects developed abroad, taking active part in those which meet their area of expertise.

Finally, Brazil's Foreign Service constantly brings up development in various areas of its international projection, even in discussions which apparently are not related to it (f), as exposed by representatives from MRE's Diplomatic Planning Secretariat (Arslanian Neto, interview, 2015). This derives greatly from its privileged regional position, but has been historically enhanced. For instance, when dealing with security-related subjects, Brazil tries to bind the solution to instability to development matters, pointing towards the need to promote the necessary conditions for a lasting solution to the sources of instability. In human rights discussions, Brazil brings up the need to tackle economic rights together with political and civil rights. In this sense, Brazil builds its international image as a promoter of global development, searching to establish the necessary conditions everywhere. 
Besides development, Brazilian foreign policy has been historically interested in guaranteeing its autonomy from stronger actors. This search for autonomy has been conducted through different strategies, as presented by Gelson Fonseca Jr (1998) ${ }^{10}$ and Vigevani and Cepaluni (2007). This objective is closely related to development, as some measures undertaken by Brazil domestically need not receive foreign criticism or intervention. Therefore, the new status achieved by Brazil in its relations with the USA and the EU was of utmost importance to its development strategy, as these central countries' disloyal trade practices and positions regarding international financial regulation were sharply criticised by Brazilian Foreign Service. In order to do so, Brazil was able to count on the support from many periphery and semi-periphery actors, which were similarly affected by central policies. Besides gathering support for its positions multilaterally, Brazilian diplomatic expansion was responsible for generating the necessary environment for national business to grow overseas.

The pursuit of development and autonomy internationally endured intense criticism domestically and abroad. Therefore, considerations on foreign policymaking are of utmost importance when trying to grasp the definition of determinate objectives of Brazilian foreign policy in the period. Maintaining large coalitions with similar actors was a constant challenge to the MRE, and scarce domestic support for its expansion internationally was obtained until some business sectors were convinced of the gains they could collect. Putnam's (1988) two-level game is of great value in trying to understand the positions pursued in multilateral forums, as agricultural and industrial sectors interests had to be conciliated in trade negotiations, for example. In spite of all the challenges faced, the last line of action certainly played a major role in increasing the chances the others had of succeeding.

\section{The Turkish case}

The Republic of Turkey has been intensely involved in a myriad of regional security dynamics, which were responsible for security aspects dominating a large part of Turkish foreign policy agenda. The establishment of the Republic in 1923 occurred in the midst of the interwar period, after the Ottoman Empire's defeat in World War I. The partition of the former Ottoman state led to the destabilisation of the Middle East, as the artificial division of the region between France and the UK and later involvement of the Cold War superpowers added fuel to tensions that were previously under control, such as those between different ethnic and religious groups. This instability was further increased during the Cold War and is still a major element in Turkish foreign policy. In this context, development considerations assumed a lesser role in Turkish international strategy, especially as it allied itself with the Western bloc and had to play a strategic role in containing Socialist pressures in the region (Altunisik and Tür 2005).

Turkish political economic thought has been historically influenced by liberal ideas (Karadag 2010; Bedinahoglu, interview, 2015). Although some interventionism has been witnessed in the 1960s and 1970s, the Washington Consensus has been very influential since the 1980s. The crises witnessed in Turkey in the 1990s, as described by Önis (2012), 
were responsible for allowing political Islam to gain strength, ultimately leading to the rise to power of the Justice and Development Party (AKP) in 2002. The AKP conducted what has been called post-Washington Consensus neoliberalism, which was marked by the privatisation of companies, reductions in social and military expenditures (despite some public areas receiving important amounts of resources), and trade liberalisation (Bank and Karadag 2012). Meanwhile, its foreign policy has undergone some important changes regarding the expansion of its ties to the rest of the world and the improvement of relations with its neighbours (Bagci and Doganlar 2009).

Trade promotion (a) is an element of utmost importance to Turkish foreign policy. Since the 1980s, the Turkish development strategy has focused on exporting, replacing the formerly dominant Import Substitution Industrialisation model. To tackle trade promotion, the MFA divides its activities into two categories. First, there are the bilateral commercial relations, which are led by a directorate general, or subordinate body, specifically in charge of planning bilateral relations with a region, country, or bloc. Secondly, the Deputy Undersecretary for Economic Affairs deals with broader bilaterally based commercial plans and with Turkish trade goals in multilateral forums (Diriöz, interview, 2015; Pazarci, interview, 2015).

In trade terms, Turkey perceives the European Union as a great opportunity for exports. Turkey's intention to join the European Economic Community was formalised in 1987, but was only effectively recognised in 1999. As the EU-Turkey Customs Union went into effect in 1995, Turkey gained access to European markets, with this being gradually enlarged with the later inclusion of new sectors. As pointed out by representatives from the MFA, the Customs Union presents both opportunities and challenges to the Turkish economy (Diriöz, interview, 2015). While increasing its exports to Europe, Turkey relinquished autonomy regarding its trade policy without all the gains of membership in the Union. For instance, trade agreements with third parties end up affecting Turkey directly, without it having a say in the process and without the requirement for third parties to extend their concessions to Turkey in the way agreed with the EU (Pazarci, interview, 2015).

In the 2000s, Turkey has sought to expand its exports to other regions, beyond its traditional sphere of influence, outreaching Africa and Latin America. In addition, its regional dynamics were the object of intense foreign policy actions in order to create the necessary conditions for activities expansion. Former foreign minister and prime minister Ahmet Davutoglu's rise to key positions in the AKP was accompanied by the pursuit of his ideas in the realm of foreign policy. His 'zero problems with the neighbours' policy increased the possibilities of co-operation in the Middle East, the Caucasus, Central Asia, and the Balkans and allowed for Turkish companies to enhance their exports to the countries in these regions (Walker 2007; Kardas 2013). Regional organisations assumed special importance, as the Economic Co-operation Organisation in Central Asia and the Organisation of the Black Sea Economic Co-operation were deemed important forums for the expansion of productive activities. Turkish competitiveness in many sectors led to it becoming an important source of goods for all regions it is part of (Bezwan, interview, 2015; Kirisci 2009). 
Concerning investments (b), Turkey has deep interests in increasing both FDI in the national territory and Turkish investments overseas. In order to make Turkey more appealing to foreign investors, Turkey counts on an agency, Investment Support and Promotion Agency (ISPAT), directly charged with this task. ISPAT has consultants working in many countries of the Organisation for Economic Co-operation and Development (OECD) and other capital-abundant states (ISPAT 2015). Turkey's neoliberal paradigm influences its relations to FDI. So, the attraction of FDI focuses mainly on making national opportunities visible and to a lesser extent on imposing certain rules on investors. Turkish Airlines appears as an important tool to promote Turkish companies abroad, connecting foreign business people to Turkey. As an operator that flies to most countries, it is deeply connected to pursuing business opportunities abroad and to promoting FDI in Turkey (Diriöz, interview, 2015; Pazarci, interview, 2015; Cagaptay 2013).

Turkey's business people can be divided into two large groups: Istanbul internationalised companies and the 'Anatolian Tigers'. The first have been historically the backbone of Turkish economy, largely influencing politics, while the second are composed of recently empowered small and medium enterprises in the Asian part of Turkey (Uzgel, interview, 2015; Karadag 2010). In spite of the AKP's neoliberal orientation, it has been known for greatly supporting both groups in order to ensure their competitiveness abroad (Bedinahoglu, interview, 2015). In this sense, the normalisation of relations with neighbours, including with the Kurdish Regional Government (KRG) in Iraq, has been of utmost importance for this (Yilmaz, interview, 2015). According to the Turkish ambassador to Brazil, Turkey proudly holds the position of the world's second largest contractor - just after China (Diriöz, interview, 2015).

During the AKP's rule, Turkey has increased its participation in multilateral forums (c). The emerging Turkish situation has led it to join semi-periphery coalitions regarding multilateral subjects. However, its traditional association with central bodies, such as the OECD and the North Atlantic Treaty Organisation (NATO), and its adherence to neoliberal principles contributed to it assuming a less confrontational position. For instance, Turkey briefly joined WTO's G-20, but later left the group, as its positions regarding the subject were more in line with those of the central countries. Its overall position regarding trade negotiations is of promoting liberalisation globally (Diriöz, interview, 2015). According to MFA representatives, Turkey still needs to overcome some barriers in terms of agricultural markets, but is ready to further this process if it is matched by the rest of the world (Pazarci, interview, 2015). In this sense, Turkey feels extremely satisfied with its perspectives of the consumer market, because of its inclusion in European value chains and because of its competitiveness in markets in the Middle East, Balkans, Caucasus, and Central Asia.

Regarding financial discussions, Turkey joins other emerging countries when criticising the oligarchic model of decision-making in the international financial institutions (IFI). Similarly, it praised G-20's rise to a central position in terms of financial global governance. In 2015, Turkey hosted the G-20 summit as president of the body. Its presidency was marked by a technical approach to overseeing the accomplishment of the organisa- 
tion's objectives of growth and employment recovery (Moretti, interview, 2015; Diriöz, interview, 2015). In many senses, its presidency was aligned with the centre's objectives, which can be attributed to the country's neoliberalism (Karadag 2010).

Turkey's political activism in international forums has focused mainly on guaranteeing stability, which could ultimately be seen as a precondition for development, albeit not being how it was sold. Although economic considerations were an important subject for Turkish government in the $20^{\text {th }}$ century, they were usually not on the MFA's agenda. Since 2002 , one can perceive an intention of basing Turkish economic growth on its ties with its neighbours and distant regions, de-escalating tensions in order to profit economically and commercially. In this sense, tensions with the KRG and Syria were initially mitigated in order to explore investment opportunities in growing regions (Yilmaz, interview, 2015).

Ownership over resources has assumed a strategic sense in Turkish foreign policy (d), as it was closely related to security matters and regional disputes. Tensions in its southeast region regarding Kurdish autonomist/secessionist movements are seen as a threat to the state. The handling of the issue has involved intense negotiations with neighbouring countries with Kurdish populations - Iran, Iraq, and Syria - alternating between co-operation and dispute. Surrounded by three important seas, Turkey has to deal with important negotiations over sea rights. In this sense, the principles established in the UNCLOS are of utmost importance when dealing with Greece in the Aegean and Mediterranean Seas, while most of its Economic Exclusive Zone matters were handled peacefully under international law (Erciyes 2012).

The Turkish Straits have required intense Turkish diplomacy in order to ensure Turkey's right over its territory, although special international law applies as the foreign right of free passage. When discussing environmental issues, Turkey has cherished the concept of sustainable development, as its developmental needs still match some rights over environment exploration, but the subject assumes a lesser role in Turkish foreign policy. However, the process of its accession to the EU has required greater advances regarding environmental protection and legislation (Diriöz, interview, 2015).

Turkey has developed an intense co-operation strategy in recent decades (e). While external co-operation was an important element of Turkish history in the $20^{\text {th }}$ century, its provision of co-operation has sharply increased since 2000. As an OECD member, Turkey counted on European and US support in some areas of technological development, which has also been part of their strategy of maintaining a safe border zone to NATO. The Turkish goal of entering the EU has been partly based on gaining access to co-operation in different European schemes (Davutoglu 2009).

Its outreach to different regions has been closely intertwined with the provision of technical co-operation and aid to developing countries. In 1992, Turkey created the Turkish International Co-operation and Co-ordination Agency (TIKA), aiming to increase its actions in the former United Socialist Soviet Republics area, especially the Caucasus and Central Asia. TIKA has since expanded its actions to Africa, Asia, and Latin America, beyond Turkish traditional interest areas. Being directly under Turkish Prime Ministry, TIKA helps MFA improve Turkey's international image, as its co-operation projects do 
not have conditionalities. However, there is an increasing pattern of trade and investment growth towards regions and countries which are recipients of TIKA's projects (Dalogullari, interview, 2015; Akpinar 2013).

Turkey's international projection (f) has been historically concerned with security matters and regional disputes. However, one can perceive a recent pattern of agenda broadening, as new moves have been made towards conflict resolution and economic opportunities creation. This pattern can be more or less dated to AKP's rise, but has somewhat deteriorated with Turkish involvement in the Arab Spring domestic political disputes, as its support of the Muslim Brotherhood in Egypt and the Syrian Opposition has provoked recent setbacks to its relations with these two countries. Overall, the approximation process in the 2000s was responsible for increasing business opportunities for Turkish entrepreneurs (Aktoprak, interview, 2015; Esmailzadeh 2014).

Turkish participation in Cypriot disputes, as the North has sought secession with Turkish support, has been responsible for the deterioration of Greek-Turkish relations, being also seen as an obstacle to EU accession (Kramer 2000). However, the recent discovery of gas and oil reserves has led to a rapprochement in order to jointly exploit resources. In the oil field, because of its strategic position in oil and gas supply routes, Turkey has reached important deals with both suppliers and consumers to allow for its territory to be used as a connector between both sides.

Recent Turkish outreach to distant regions can be seen as a move towards greater participation in world affair and pursuing better and broader ties to the world (Kardas 2013). This is clearly related to the expansion of Turkish business activities. In this sense, Turkey has been seeking to champion the Islamic world, especially through the Islamic Conference Organisation, in order to increase its economic and commercial ties to Islamic countries. This strategy is strongly based on the AKP's Islamic nature (Yesiltas 2013).

Autonomy plays an important role in Turkish foreign policymaking, as the struggle to profit from its strategic position has been a constant in Turkish history. The bipolar dispute and current war on terror have contributed to making Turkey an actor of utmost importance to Western powers. Although mostly aligned to the USA and the EU during Cold War, Turkey, under the AKP, has sought to increase its bargain power, aiming at a more autonomous position (Murinson 2012). Its outreach to other regions is simultaneously an effect and a cause of this move, creating greater leverage for its foreign policy and greater business opportunities.

Similarly to Brazil, Turkey's strategy has to deal with domestic and international disputes in a two-level game. Harmonising demands from both business groups, the Istanbul-based group and the Anatolian Tigers, the AKP counts on great support to expand its territorial scope of action. Its international action is based less on forming coalitions, as its leadership capabilities are reduced, in part due to its conflictive regional situation and to its immediacy to great powers with greater support-gathering capabilities. 


\section{The semi-periphery's foreign policy and development}

Applying the aforementioned model to the cases has been very illustrative of how foreign policy works as a tool to promote the development of these countries. Despite their differences, the two countries' international actions have a lot in common when dealing with the expansion of national business activities, one of the main focuses of state action abroad. The pattern their strategies assumed also has a lot to do with their economic models, which are responsible for the differences in terms of their participation in multilateral forums and of how the political area of foreign policy is related to the economic one.

The two countries' initiatives regarding trade and investment present major similarities, as both have sought to expand their areas of action towards untraditional regions, searching for new opportunities for political and economic gains. Although meeting some resistance, this strategy has encountered support from businesses interested in exporting and/or investing abroad. Meanwhile, the two countries continue to seek FDI to expand domestic economic activities. This duality is a characteristic intrinsic to semi-periphery actors, where both inward and outward investment flows are of utmost importance to development, although the latter is still a recent phenomenon. This dual relation is also reflected in their co-operation strategy, in which both countries present a recent move towards providing co-operation to other countries, having sharply reduced inward flows of co-operation from central countries.

When dealing with economic, financial, and commercial discussions, Brazil and Turkey show some important differences. Brazil's history of unorthodox economic thinking, albeit recently changing towards a more liberal position, has led to a more intense approach by the MRE when criticising IFI or demanding fairer trade rules for developing nations in the WTO. Meanwhile, Turkey pursues a more neoliberal strategy, without much to say about disloyal central trade practices, as its most protected area is also agriculture - its exit from WTO's G-20 attests to that.

In terms of resource exploitation rights, both countries present a very nationalistic point of view, aiming to ensure their ownership of disputed areas, especially in the sea through UNCLOS, and their right to explore them in order to promote their development. Their overall participation in multilateral forums has seen great expansion since the beginning of the new century, which is commonly attributed to the emergence phenomenon. This is reflected in their outreach to distant regions and in their greater search for autonomy, aiming to guarantee their freedom of action.

\section{Final remarks}

Through review of FPA, IR and IPE literature, this article aimed to establish a model to understand how foreign policy helps promote a semi-periphery country's development. This model is divided into two areas of action, economic and political, each with three lines of action, namely: trade promotion; investment policy; economic, financial and commercial negotiations; resource exploration rights; international co-operation; and international 
projection. It does not seek to divide foreign policy into independent elements, but to try to organise how some discussions and actions have similar effects on development. The whole model is based on a conception of the state as an inductive actor of development.

In order to check the model's applicability, it was applied in the analysis of two semi-periphery countries, which led to important contributions to the model, especially through the conducted interviews with representatives from the two countries' foreign ministries and from other relevant agencies and with scholars. The differences in the two countries' regional context and economic model did not prevent the model from being duly applied, albeit with some important variations being witnessed. Their perspectives on world trade and economic-financial negotiations can be perceived as differing from one another - with Turkey being more in line with the centre's positions and interests. Both countries showed the dual position inherent to semi-periphery actors when co-operation and investment are analysed and a nationalistic perspective when dealing with their resources' exploitation.

Overall the model can be said to be useful to understand how semi-periphery states use foreign policy to enhance their development-promotion strategies. The model can be further expanded to reach periphery or centre countries by reducing some of the possibilities that are inherent to the semi-periphery's intermediary status. As the application to the Turkish case demonstrates, the positions commonly presented in the literature as favourable to the economies of developing countries are not necessarily espoused by these actors, in contrast to Brazil. This research was set to advance a still little explored intersection between two areas of study in IR: FPA and IPE. National development can and should be helped by national foreign policy, which is a recurring phenomenon in the current context of the rise of new actors. This article aimed to shed light on this relation, which will be further analysed in terms of the understanding of the national process of decision making and in terms of its application to other states.

\section{Notes}

1 According to Fonseca (2014: 59, our translation), developmentalism is 'the economic policy deliberately planned and/or executed by (national or sub-national) governments to transform society through production and productivity growth under industrial leadership in order to achieve desirable goals, notably overcoming economic and social problems, under the institutional boundaries of the capitalist system'.

2 Cervo (2008) presents an interpretation of Brazilian diplomatic history that is based on the concept of paradigm, which he understands as a way to organise the object of his observation and analysis, albeit recognising its smaller scientific rigidity when compared to the use of the term in natural sciences.

3 According to Cervo (2008), the developmentalist paradigm is based on the notions of transition conscience, development as a foreign policy vector, realist conduct, pursuing a complex society's interests, development as industry expansion, and foreign policy excellence through autonomy, foreign co-operation, flexible trade policy, and defence policy subordination to economic goals.

4 According to Cervo (2008), this paradigm was marked by a subservient position in the political sphere, the elimination of the notions of national interest and national development project, together with many developmentalist practices, and regression in terms of structure and history.

5 Together with the MAPA, the MRE and the MDIC have created a website to promote trade and investments, available at: <http://www.investexportbrasil.gov.br/?l=en>. 
6 One of Brazil's top technology enterprises, Embraer sold one of its aircrafts for the first time to Uruguay in 1976, counting on the support of DPR (Souza, interview, 2015).

7 While establishing relations with the People's Republic of China (1974), Itamaraty helped Vale export its mineral goods in 1973 .

8 Brazil has already signed ACFIs with Angola, Colombia, Malawi, Mexico, and Mozambique and is in advanced stages of negotiation with Algeria, Chile, Peru, and Vietnam. Further ACFIs may be signed with the Dominican Republic, Morocco, Singapore, and Tunisia (Moretti, interview, 2015).

9 It was responsible for making the biggest decisions on the Round's themes. First, it was composed of the United States, the European Union, Japan, and Australia; then, the last two were replaced by Brazil and India.

10 Fonseca $\operatorname{Jr}$ (1998) understands Brazilian foreign policy under the military regime as searching for 'autonomy through distance', while foreign policy in the 1990s as 'autonomy through participation'. Following this classic analysis, Vigevani and Cepaluni (2007) propose that Lula's diplomacy searched for 'autonomy through diversification'.

\section{References}

Agência Brasileira de Cooperação (ABC). 2015. Histórico. Available at: http://www.abc.gov.br/SobreABC/Historico [Accessed on 14 December 2015].

Akpinar, Pinar. 2013. 'Turkey’s Peacebuilding in Somalia: The Limits of Humanitarian Policy'. Turkish Studies 14 (4): 735-757.

Aktoprak, Elçin. 2015. Personal interview by author. Ankara. 20 November.

Altunisik, Meliha Benli and Özlem Tür. 2005. Turkey: Challenges of continuity and change. Oxon: Routledge Curzon.

Amora, Paulo Roberto and Márcio Lopes Corrêa. 2015. Personal interview by author. Brasília. 6 October.

Amorim, Celso. 2011. Conversas com jovens diplomatas. São Paulo: Benvirá. . 2015. Teerã, Ramalá e Doha: Memórias de uma política externa ativa e altiva. São Paulo: Benvirá.

Amsden, Alice H. 2001. The Rise of the Rest: challenges to the west from late-industrializing economies. New York: Oxford University Press.

Arslanian Neto, Michel. 2015. Personal interview by author. Brasília. 6 October.

Arrighi, Giovanni. 1990. 'The Developmentalist Illusion: A Reconceptualization of the Semiperiphery'. In William G Martin (ed), Semiperipheral States in the World-Economy. Westport: Greenwood Press, pp. 11-42.

Bank, André and Roy Karadag. 2012. 'The Political Economy of Regional Power: Turkey under the AKP' GIGA Working Papers 204.

Baumann, Renato and Heloiza C Moreira. 1987. 'Os incentivos às exportações brasileiras de produtos manufaturados - 1969/85’. Pesquisa e Planejamento Econômico 17 (2): 471-490.

Bedinahoglu, Nazan. 2015. Personal interview by author. Ankara. 23 November.

Bezwan, Naif. 2015. Personal interview by author. Porto Alegre. 20 August.

Cagaptay, Soner. 2013. 'Defining Turkish Power: Turkey as a Rising Power Embedded in the Western International System. Turkish Studies 14 (4): 797-811. 
Caporaso, James A et al. 1986. 'The Comparative Study of Foreign Policy: Perspectives on the Future'. Paper delivered at $27^{\text {th }}$ Annual Meeting of the International Studies Association, Anheim.

Cervo, Amado Luiz. 2008. Inserção Internacional: formação dos conceitos brasileiros. São Paulo: Saraiva.

Costa Filho, Ronaldo. 2015. Personal interview by author. Brasília. 5 October.

Dalogullari, Fatih. 2015. Personal interview by author. Ankara. 18 November.

Danese, Sérgio. 1999. Diplomacia Presidencial: história e crítica. Rio de Janeiro: Topbooks.

Davutoglu, Ahmet. 2009. 'Turkish Foreign Policy and the EU in 2010'. Turkish Policy Quarterly 8 (3): 11-17.

Diriöz, Hüsseyin. 2015. Personal interview by author. Brasília. 7 October.

Erciyes, Çagatay. 2012. Maritime Delimitation \& Offshore Activities in the Eastern Mediterranean: Legal \& Political Perspectives, Recent Developments. Ankara: Turkish Ministry of Foreign Affairs.

Esmailzadeh, Yaser. 2014. 'Turkey's Foreign Policy towards the Middle East (2002-2013)'. Switzerland Research Park Journal 103 (1): 327-335.

Feder, Gershon. 1982. 'On Exports and Economic Growth'. Journal of Development Economics 12: $59-73$.

Fonseca, Carlos da. 2015. 'A Presença Empresarial Brasileira na América do Sul: Implicações para a Política Externa'. Cadernos de Política Exterior 1 (1): 195-230.

Fonseca, Pedro Cezar Dutra. 2014. 'Desenvolvimentismo: a construção do conceito'. In André Bojiklan Calixtre, André Martins Biancarelli and Marcos Antonio Macedo Cintra (eds), Presente e futuro do desenvolvimento brasileiro. Brasília: IPEA, pp.29-78.

Fonseca Jr., Gelson. 1998. A legitimidade e outras questões internacionais. São Paulo: Paz e Terra.

Furtado, Celso. 2000. Introdução ao Desenvolvimento: introdução histórico-estrutural. Rio de Janeiro: Paz e Terra.

Gerschenkron, Alexander. 1961. Economic Backwardness in Historical Perspective: A Book of Essays. New York: Frederick A. Praeger.

Hudson, Valerie M and Christopher S Vore. 1995. 'Foreign Policy Analysis Yesterday, Today, and Tomorrow'. Mershon International Studies Review 39 (2): 209-38.

Hyman, Gerald F. 2010. Foreign Policy and Development: Structure, Process, Policy, and the Drip-byDrip Erosion of USAID. Washington: CSIS.

Jaguaribe, Hélio. 2013a. Estudos Filosóficos e Políticos. Brasília: FUNAG. 2013b. O Nacionalismo na Atualidade Brasileira. Brasília: FUNAG.

Karadag, Roy. 2010. 'Neoliberal Restructuring in Turkey: From State to Oligarchic Capitalism'. MPIfG Discussion Paper 10 (7).

Kardas, Saban. 2013. 'Turkey: A Regional Power Facing a Changing International System' Turkish Studies 14 (4): 637-60.

Kirisci, Kemal. 2009. 'The transformation of Turkish foreign policy: The rise of the trading state'. New Perspectives on Turkey 40: 29-57.

Kramer, Heinz K. 2000. A Changing Turkey: The Challenge to Europe and the United States. Washington: The Brookings Institution. 
Leite, Iara Costa. 2012. 'Cooperação Sul-Sul: Conceito, História e Marcos Interpretativos'. Observador On-line 7 (3): 1-40.

Lima, José Alfredo Graça. 2015. 'VI Cúpula do BRICS: Perspectivas e Resultados'. Cadernos de Política Exterior 1 (1): 11-26.

Marroni, Etienne Villela. 2013. Política Internacional dos Oceanos: Caso brasileiro sobre o processo diplomático para a plataforma continental estendida. PhD Thesis, UFRGS, Brazil.

Maxwell, Simon. 2007. 'How do development and foreign policy connect?'. Overseas Development Institute Opinion Papers 93.

Moretti, Maria Norberto. 2015. Personal interview by author. Brasília. 5 October.

Murinson, Alexander. 2012. 'Turkish Foreign Policy in the Twenty-First Century' Mideast Security and Polity Studies 97: 1-31.

Önis, Ziya. 2012. 'The Triumph of Conservative Globalism: The Political Economy of the AKP Era'. Turkish Studies 13 (2): 135-52.

Pazarci, Bercan. 2015. Personal interview by author. Ankara. 19 November.

Putnam, Robert D. 1988. 'Diplomacy and Domestic Politics: The Logic of Two-Level Games'. International Organisation 42 (3): 427-60.

Santos, Marcelo. 2013. 'A presença brasileira na América do Sul: ações e instrumentos de política externa’. Análisis Político 77: 195-210.

Silva, André Luiz Reis da. 2013. 'Os países emergentes na política internacional: O grupo Next Eleven (n-11) e as convergências com a política externa brasileira'. Estudos Internacionais 1 (2): 205-22.

Silva, André Luiz Reis da and Eduardo Munhoz Svartman (eds). 2014. Política Externa Brasileira durante o Regime Militar (1964-1985). Curitiba: Juruá.

Souza, Amaury de. 2002. A Agenda Internacional do Brasil: um estudo sobre a comunidade brasileira de política externa. Rio de Janeiro: CEBRI.

Souza, Carlos Henrique Moscardo de. 2015. Personal interview by author. Brasília. 6 October.

Uzgel, Ilhan. 2015. Personal interview by author. Brasília. 20 November.

Vigevani, Tullo and Gabriel Cepaluni. 2007. 'A política externa de Lula da Silva: a estratégia da autonomia pela diversificação'. Contexto Internacional 29 (2): 273-335.

Vigevani, Tullo and Haroldo Ramanzini Jr. 2014. ‘Autonomia, Integração Regional e Política Externa Brasileira: Mercosul e Unasul'. Dados 57 (2): 517-52.

Visentini, Paulo G. Fagundes and André Luiz Reis da Silva. 2010. 'Brazil and the Economic, Political, and Environmental Multilateralism: the Lula years (2003-2010)'. Revista brasileira de politica internacional 53 (especial): 54-72.

Yesiltas, Murat. 2013. 'The Transformation of the Geopolitical Vision in Turkish Foreign Policy' Turkish Studies 14 (4): 661-87.

Yilmaz, Arzu. 2015. Personal interview by author. Ankara. 18 November.

Walker, Joshua W. 2007. 'Learning Strategic Depth: Implications of Turkey's New Foreign Policy Doctrine.' Insight Turkey 9 (3): 32-47.

Wallerstein, Immanuel. 1988. 'Development: Lodestar or Illusion?' Economic and Political Weekly 23 (39): 2017-23. 
. 1976. 'Semi-Peripheral Countries and the Contemporary World Crisis' Theory and Society 3 (4): 461-83.

\section{Acknowledgements}

The authors thank the Research Support Foundation of the State of Rio Grande do Sul (Fundação de Amparo à Pesquisa do Estado do Rio Grande do Sul - FAPERGS), and the National Council for Scientific and Technological Development (Conselho Nacional de Desenvolvimento Científico e Tecnológico - CNPq) for funding this research.

\section{About the authors}

Alexandre Piffero Spohr is PhD student in Political Science at the Federal University of Rio Grande do Sul (UFRGS), Brazil. He holds a Master's degree in Political Science and a Bachelor's degree in International Relations. He researches Brazilian Foreign Policy Analysis and Development. His research interests include emerging powers, foreign policy analysis, and international political economy, aiming to combine these fields of study to allow for a deeper and more comprehensive approach to international relations. He is currently part of a project on Brazilian and Turkish foreign policies and on Dilma's foreign policy and studies Brazilian foreign policy decision-making process.

André Luiz Reis da Silva holds a PhD in Political Science from the Federal University of Rio Grande do Sul (UFRGS), Brazil. He is Associate Professor and Dean of Graduate Programme in International Strategic Studies at the same institution, and Editor-in-Chief of the journal Conjuntura Austral: Journal of the Global South. He researches the International Relations of Southern Countries, focusing on Brazilian foreign policy and Emerging Powers in Asia and Africa. He was a post-doctoral fellow at the School of Oriental and African Studies (SOAS), University of London (2013). Currently, he is developing research on Brazilian and Turkish foreign policy in a comparative perspective and another study on foreign policy under Dilma Rousseff's presidency in Brazil.

Received on 5 April 2016 and approved for publication on 28 July 2016.

(cc) BY-NC https://creativecommons.org/licenses/by-nc/4.0/ 